\title{
Indicators of agricultural intensity and intensification: a review of the literature
}

\author{
Irune Ruiz-Martinez, ${ }^{1}$ Elisa Marraccini, ${ }^{2}$ Marta Debolini, ${ }^{3}$ Enrico Bonari ${ }^{1}$ \\ 'Institute of Life Sciences, Scuola Superiore Sant'Anna, Pisa, Italy; ${ }^{2}$ UP 2012-10-103 \\ PICAR-T, Polytechnic Institute LaSalle Beauvais, France; ${ }^{3}$ INRA, UMR 1114 EMMAH, \\ Avignon, France
}

\begin{abstract}
Since the 1960s, research has dealt with agricultural intensification (AI) as a solution to ensure global food security. Recently, sustainable intensification (SI) has increasingly been used to describe those agricultural and farming systems that ensure adequate ecosystem service provision. Studies differ in terms of the application scales and methodologies, thus we aim to summarize the main findings from the literature on how AI and SI are assessed, from the farm to global levels. Our literature review is based on 7865 papers selected from the Web of Science database and analysed using CorText software. A further selection of 105 relevant papers was used for an in-depth full-text analysis on: i) farming systems studied; ii) related ecosystem services; iii) indicators of intensity; and iv) temporal and spatial scales of analysis. Through this two-step analysis we were able to highlight three main research gaps in the AI research indicators. Firstly, the farming systems analysed for assessing $\mathrm{AI}$ are often quite simplified or monoculture-oriented, and they do not take the diversity and complex organisation of farming systems into account. Secondly, these studies mainly focus on northern countries or developing countries, whereas there is a gap of knowledge in Mediterranean areas, which are the areas with a high complexity of farming systems and diversity in ecosystem services. Finally, AI is mostly assessed through nitrogen inputs and
\end{abstract}

Correspondence: Irune Ruiz-Martinez, Institute of Life Sciences, Scuola Superiore Sant'Anna, via Santa Cecilia 3, 5612 Pisa, Italy.

Tel.: +39.050883503 .

E-mail: i.ruizmartinez@sssup.it

Key words: Land use intensity; ecosystem services; farming systems; indicators; spatial scales; sustainability.

Acknowledgements: IRM acknowledges the research grant from Scuola Superiore Sant'Anna of Pisa (Italy) and EM the PICAR-T research units for the support in the English review.

Conference presentation: SIA XLIII Congress, Pisa, 2014.

Received for publication: 29 January 2015.

Revision received: 22 April 2015.

Accepted for publication: 25 April 2015.

(C) Copyright I. Ruiz-Martinez et al., 2015

Licensee PAGEPress, Italy

Italian Journal of Agronomy 2015; 10:656

doi:10.4081/ija.2015.656

This article is distributed under the terms of the Creative Commons Attribution Noncommercial License (by-nc 3.0) which permits any noncommercial use, distribution, and reproduction in any medium, provided the original author(s) and source are credited. economic yield, which are used the most both at very local and global levels. Intermediate regional or local levels, which are relevant for policy implementation and local planning, are often neglected.

\section{Introduction}

Since the escalation of agricultural commodity prices, agricultural intensification (AI) has increased its importance due to the debate on global food security (Buckwell, 2014). This debate started in the 1960s, when Boserup (1965) used intensification to explain higher levels of agricultural productivity associated with higher population densities in agriculture. Turner and Doolittle (1978) defined AI as the amount of output per unit area and per unit time. However, noting that output data were scarce, they developed a proxy scale of AI based on two input variables: frequency of cropping and the use of agricultural technology.

Since then, several authors have exploited this theory together with others, and the terminology has been modified over the years often becoming quite ambiguous.

Likewise, some publications have attempted to clarify the difference between agricultural intensification and intensity (Shriar, 2000; Kleijn et al., 2009; Dietrich et al., 2012) however they are still often used indifferently. We believe that there is no univocal definition for the different terms used, such as agricultural intensity, land use intensity (LUI) or AI, and therefore we begin by trying to differentiate between them.

In general, agricultural intensity is defined as the ratio of inputs and outputs within an agricultural system, i.e., in terms of yield per land area and per input unit (Turner and Doolittle, 1978; Shriar, 2000, 2005; Herzog et al., 2006) or alternatively as the sum of different categories of input costs and the total usable agricultural area of the farm (Teillard et al., 2012). Therefore either output-oriented (production) or input-oriented (utilisation) measures can be used to describe agricultural intensity.

Many studies tackling the environmental impacts of agricultural intensity have focused on a single component, such as nitrogen input (Kleijn et al., 2009; Fumagalli et al., 2011; Temme and Verburg, 2011; Overmars et al., 2014) or pesticides (Geiger et al., 2010; Jepson et al., 2014). Others have used proxy indicators of agricultural intensity, such as yield or profitability (Caraveli, 2000; Stoate et al., 2009; Schneider et al., 2011; Kuemmerle et al., 2013; Niedertscheider and Erb, 2014) or the relative amount of arable fields (Schneider et al., 2011; Tuck et al., 2014). In regional studies, land use intensity is referred to the area required to produce one unit of output or the yield per time and area unit (Lambin et al., 2000). In dynamic terms, we also found explicit definitions for the term AI or LUI changes (i.e., intensification) as the resulting process of land use changes over time or the changes in yields and land productivity (Shriar, 2005). In fact, recently all approaches have been spatially-explicit and based on the analysis of the changes in land uses (Lambin et al., 2000). Main results of these works confirmed that most of land use changes in Europe occurred along gradients of management intensity (Rounsevell et al., 2003; 
Ewert et al., 2005; Foley, 2005; Rounsevell et al., 2006; Kleijn et al., 2009; Renting et al., 2009; Foley et al., 2011; Lambin and Meyfroidt, 2011; Erb, 2012; Rounsevell et al., 2012; Allan et al., 2014). Likewise, intensification is usually measured as a resulting process from land use changes (e.g., abandonment, fragmentation or urban sprawl) and conversely, intensity and intensification affect land use changes through of different pathways as the land pressure in terms of profitability. In other words, AI can be related to land scarcity or to its high cost, where land is available, combined with the supply of ecosystem services (Byerlee et al., 2014).

This has also triggered others assumptions, such as defining intensification as the replacement of heterogeneity in habitat structure, in time and space, with homogeneity (Benton et al., 2003). Tscharntke et al. (2005) defined it as the conversion of complex natural ecosystems into simplified managed ecosystems with a high resource use and a generally higher input and output.

In addition to defining AI or LUI, it is also necessary to create an application framework for the concept, as well as to analyse how it should be measured, and which indicators should be used and under what conditions. In fact, identifying the degree of intensification may also increase the knowledge of the impact of land use change on ecosystem services across different landscapes.

Unlike a natural system, a system managed through intensification is able to produce abundant food, however reducing other ecosystem services (Foley, 2005), would thus be important in understanding how ecosystems are altered by agricultural intensification (Matson, 1997; Snapp et al., 2010). Indeed, there is a general agreement on the idea that $\mathrm{AI}$ reduces the quantity and quality of the services that ecosystems provide, including the loss of biodiversity (Allan et al., 2014; Egorov et al., 2014; Overmars et al., 2014; Tuck et al., 2014) and the water and soil quality (Foley, 2005; Stoate et al., 2009; Snapp et al., 2010; Zhang et al., 2012; Tittonell and Giller, 2013; Williams and Hedlund, 2014). Therefore an overall vision that includes all the indicators in the literature, thus increasing the empirical basis, is a pertinent and realistic tool to measure agricultural performance and monitor progress in order to produce detailed knowledge of the intensity of agricultural land use (Erb et al., 2009; Temme and Verburg, 2011; Rousevell et al., 2012).

In this study, $\mathrm{AI}$ is measured as a result of farming practices at any given time based on indicators and proxies. The review will therefore answer the following two research questions: What are the effects of AI and how are they measured? Which agricultural land uses and systems are linked to $\mathrm{Al}$ ?

In order to compare the various ways of measuring the AI/LUI as well as the approaches and aims, a bibliometric analysis was carried out to place both these topics in the relevant scientific contexts (e.g., land use science, food planning and ecosystem services) and to make an analysis on a farmland to global scale. A subsequent qualitative and statistical analysis on the full texts of selected papers highlighted the interactions among variables indirectly related to AI to identify major research gaps and recommendations. In order to systematically review the obtained papers' database and highlight their main relevant concepts, we applied an analysis grid containing the following criteria: i) the main declared topic related to $\mathrm{AI}$ research; ii) the literature definition used for identifying AI concept; iii) and the methods applied to evaluate AI.

\section{Materials and methods}

This paper involves two main steps. Research papers were selected in both steps according to the PRISMA (preferred reporting items for systematic reviews and meta-analysis) flowchart (Figure 1) (Liberati $e t$ al., 2009).

In the first step, we provided an overview of how the concept of AI has been used in the literature. We reviewed international studies on AI from the first publications in 1975 until now, and from the international bibliographic database Web of Science (WoS). The papers obtained were analysed using the bibliometric software CorText (Tancoigne et al., 2014). Software CorText is a platform dedicated to the cleaning and treatment of large textual corpuses with the aim of synthesising and analysing big data, whether structured or unstructured (IFRIS, 2014).

In the second step, starting from the whole database and also considering different bibliographic databases (Scopus, WoS and Google Scholar), we selected various relevant papers. The full texts of these papers were then analysed in depth in order to answer our research questions.

\section{Bibliometric analysis}

The bibliometric analysis was performed using the CorText software (IFRIS, 2014), which enabled us to upload data sets and run the different analytical process in order to perform lexical analysis and mapping the structure and the dynamics of the corpus. The common procedure is specified as follows: i) calculation of the frequency of occurrence of each term; ii) normalisation of these occurrence and co-occurrence measurements as proximity measurements to link the nodes (Tancoigne et al., 2014). CorText manager recommends choosing direct measures for heterogeneous network like chi-squared test, which only takes into account the raw co-occurrence number between two nodes. The dataset is analysed through a lexical extraction of the title and abstract from the selected papers, which supply key information on the most co-common topics. Data collection was carried out using keywords including various synonyms and combinations of the concept. A systematic search in the WoS database (main keywords: agricultural intensification OR land use intensity OR agricultural intensity), combined with others [sustainability OR ecosystem services OR land use modelling (Table 1); Timespan: 1975-2014; Search language: English], yielded 7865 publications that were retrieved and imported as a corpus to the CorText Manager Software for data analysis.

The resulting map based on a keywords analysis identified the most relevant terms, the dynamics across the links and nodes, the interactions between them and the distribution along with their weight.

Table 1. Selection of keywords for retrieval of papers.

Farming system intensity

Cropping system intensity

Land system intensity

Farming system dynamics

Land use intensity

Agricultural intensity
Periurban areas

Mediterranean areas

Ecosystem services

Landscape services

Sustainability

Indicators

Land use modelling

Urban expansion 
Cluster analysis highlighted the aggregation of the most frequently used terms. Nodes and links between clusters captured the information flows between those aggregations (IFRIS, 2014).

\section{Selection of papers for the full-text analysis}

Publications were included in the selection if they provided enough evidence on the way of leading the AI within our context. Firstly, a filter was applied on approximately 300 publications by screening the title and abstract, and secondly by full text on around 160 , thus yielding the final selection.

The study was based on the concept that agricultural intensity is defined as the result of farming practices at any given time, and intensification is considered as the total process rather than one condition at any particular time. We filtered the publications that met the following criteria: the relevant scientific disciplines (studies related to landscape agronomy, landscape planning and land use science); the presence of a quantitative approach (studies had to quantify the changes in agricultural land use or the indicator values); assessments of ecosystem services (studies had to quantify the land use intensity as a proxy for the assessment of ecosystem services delivered by agricultural systems); and the spatial level of the analysis (analyses beyond the field gate, so from the farm level to a global level).

The selection for the full-text analysis resulted in a final corpus of 105 papers.

\section{Full-text analysis}

From our 105 papers sample, the items searched for were: i) the case study location and the spatial level of the analysis; ii) the methods applied and the presence of thresholds in the evaluation of the sustainability of AI/LUI. We also collected data on the ecosystem services, the farming systems or land uses in which AI was analysed and the indicators taken into consideration. The set of variables (ecosystem services, farming systems and indicators) were coded and consisted of binary and discrete variables within the database. These variables were calculated through frequency and descriptive analyses and points of significance for both ecosystem services and indicators at different scales. Statistical methods enhanced the understanding of the data and were used for comparisons.

We first hypothesised that there are several indicators driving the AI that depend on initial conditions, such as geographical context and farming system (Rounsevell et al., 2003; Geiger et al., 2010; Overmars et al., 2014). Based on the literature reviewed, we further hypothesised that AI needs to be measured with several indicators, since a single indicator is not able to assess $\mathrm{AI}$ [(e.g., nitrogen or pesticides applications (Herzog et al., 2006; Overmars et al., 2014); ratio of livestock numbers (computed as livestock units) (Rounsevell et al., 2005); net primary production (Erb et al., 2009; Krausmann et al., 2012)].

We also wanted to define sustainability thresholds on the specific indicators under any context (Paracchini et al., 2011). On the other hand, we relied on the premise that an intensive system or cropland, which, in turn, is explicitly managed to maintain other ecosystem services, may be able to support a broader portfolio (Foley, 2005; Bommarco et al., 2013).

\section{Results}

\section{Bibliometric research}

The semantic maps represent the results of the network analysis, which identified the main topics around AI. They are composed of clusters, which represent the most different co-occurrence topics regarding
AI. The most frequent topics are those related to land use intensity (yellow cluster) and those on land use change and climate change (red cluster). In fact, according to Figure 2, the most frequent are represented by the bigger dimension of the cluster because of the dimension of the circles is proportional to the number of retrievals and nodes are linked according to different types of proximity (measure: chi-squared test).

The publications found in these clusters marginally tackle the question of the sustainability of the intensification of farming systems and the importance of analysing it from a regional approach. Other smaller clusters are more specific (e.g., biodiversity or soil loss), but supply quantitative information on intensity indicators and intensification in terms of particular ecosystem services (Figure 2).

Thus, an overview of the research field was obtained. The over-time analysis (Figure 3) was of particular interest in revealing the different applications of AI over the last few decades knowing when the most frequent topics were used. Unlike the previous it was only analysed with the co-occurrence of the terms, in this analysis both years and terms were taken into consideration resulting a mapping of co-occurrence of the main common topics placed in terms of time (from 1975 to 2014).

In fact, between 1996 and 2007, research in this field was related to a greater proportion of topics such as changes in land use, the sustainable development of farming systems, and soil and water quality. Between 2010 and 2014, the density of nodes and links is less on issues related to land use, land cover or land use intensity as proxies to measure AI, whereas the main ecosystem services are linked to soil and water quality. These are therefore the emerging research areas, and underline the permanence over time of the interest in water and soil resources.

\section{In depth analysis on full-text papers}

Of the 105 selected papers, 50 were reviews and 55 were research articles containing 225 case studies distributed across all continents. The European Union constituted $33 \%$ of these studies and applied case stud-

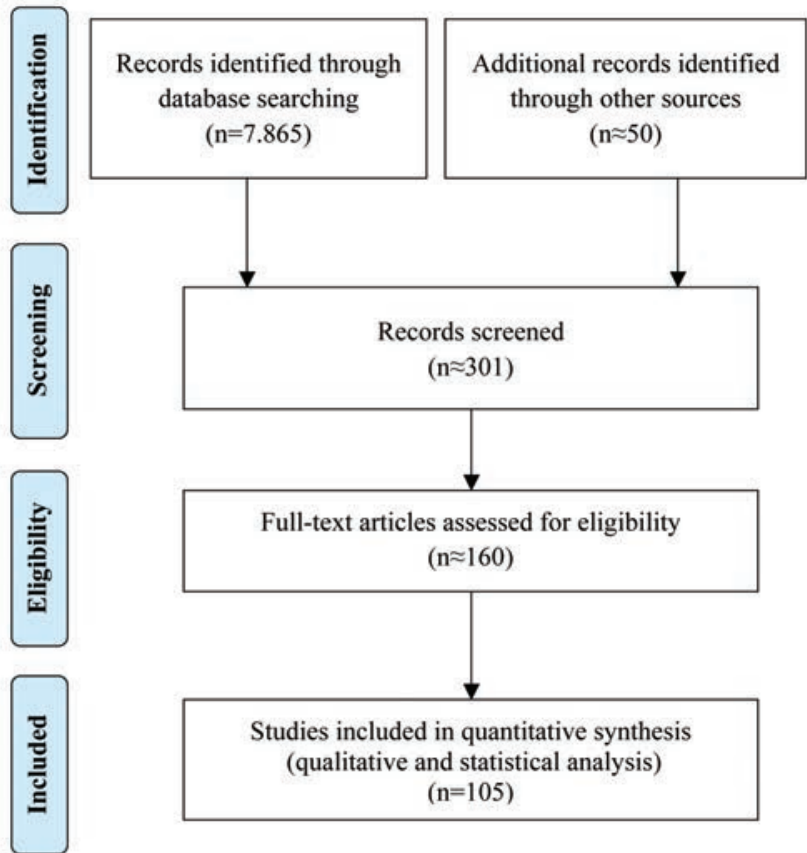

Figure 1. Preferred reporting items for systematic reviews and meta-analysis diagram according to Liberati et al. (2009). 
ies (77\%), while the rest focused on Asia, the Philippines, Africa, South America and the USA. In the European papers, the case studies represented in the sample were highly distributed in Germany (8\%), UK (8\%) and Netherlands (7\%) followed in a lower tendency by Mediterranean case studies like Spain (7\%), France (6\%) and Italy (6\%). The low number of cases may be influenced by the lower degree of intensive farming in south-eastern Europe (Caraveli, 2000). The case studies are mostly located at continental, national or administrative levels. Very few apply to agro-ecoregions or natural regions and none of them concerned the Mediterranean basin at this level, whereas Mediterranean case studies are mainly targeted at national (Caraveli, 2000) or very local levels (Serra et al., 2008; Salvati and Tombolini, 2013).

\section{Studying past dynamics to predict future trends of agricultural intensification}

Several analyses describing the global trends in production yields have been carried out on AI (Matson, 1997; Cassman, 1999; Rudel et al., 2009). There is increasing interest in quantifying agricultural inputs related to land productivity at a local scale, considering variables that can be easily retrieved from interviews with farmer (Herzog et al., 2006; Reidsma et al., 2006; Armengot et al., 2011; Dietrich et al., 2012; Gaudino et al., 2014). Many studies have explored the statistical relationships between crop yield and land use (Rudel et al., 2009; Ewers et al., 2009) and in the last few years there has been an increasing interest in predicting future changes in land-use intensity (Lambin et al., 2000). Using a scenario analysis, a dynamic and spatially explicit land-

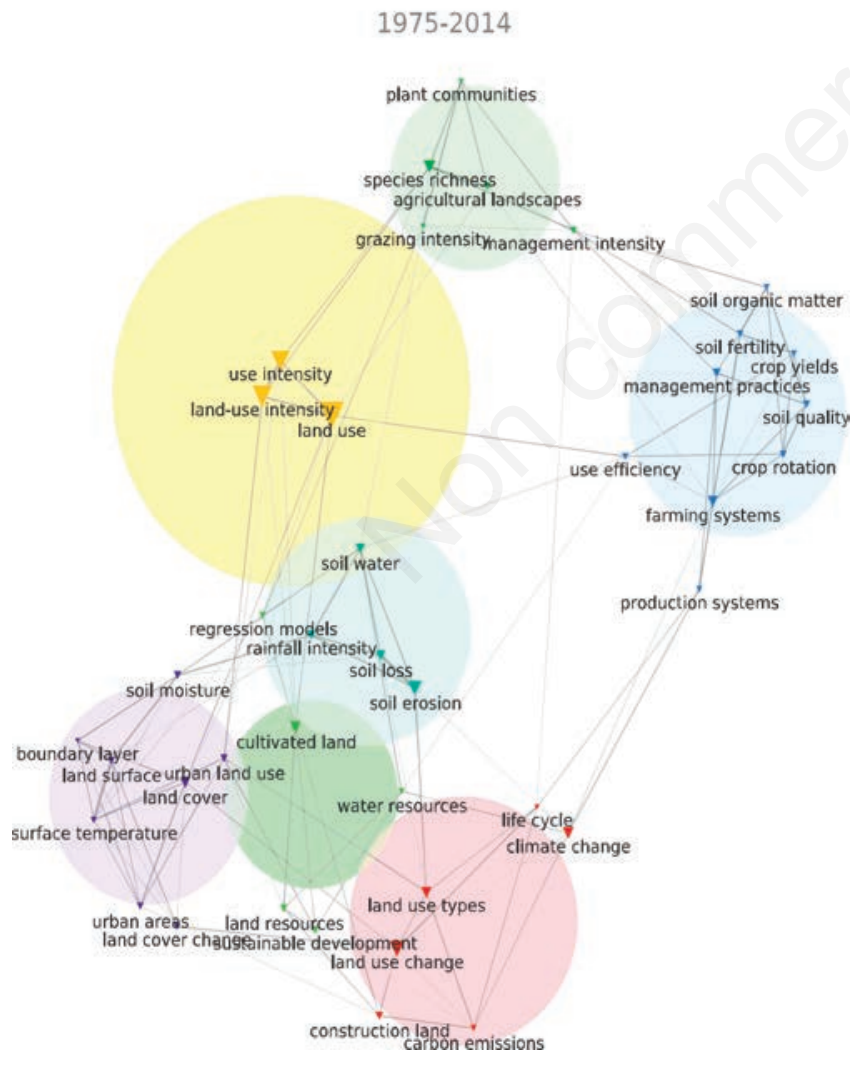

Figure 2. Combined mapping and clustering of the most frequent keywords that appeared in the research field in the period 19752014 using CorText software. The dimension of the circles is proportional to the number of retrievals. Nodes are linked according to different types of proximity (measure: chi-square test). use change model was presented for the analysis of land use in small regions at a fine spatial resolution (Verburg et al., 2002; Lima et al., 2011). Modelling techniques have been developed for predicting future land use, thus supporting decision-making on important issues such as climate variability (Rounsevell et al., 2003; Rounsevell et al., 2005; Audsley et al., 2006). Several studies (Table 2) have used such models to spatially and explicitly quantify the trade-off between productivity, cropland use and intensity of land use (Ewers et al., 2009; Barretto, 2013). Recently, a quantitative method called Intensity Analysis has been used to characterise patterns of change at different levels and over several time intervals, and to explore the processes and drivers of change (Aldwaik and Pontius, 2012; Huang et al., 2012).

\section{Few indicator thresholds of agricultural intensification}

Each indicator performs differently according to the geographical/ environmental/socio/economic contexts in which it is measured. Defining a threshold maximises the benefits obtained from a given parcel of land in a sustainable way over a long period of time (Paracchini et al., 2011). Thresholds also reveal the spatial variability, or whether a system is sustainable in any context. In our review sample there are few papers where thresholds are defined (13\%), including thresholds always using the same indicators. Some studies propose future scenarios with intensity thresholds based on nitrogen input, as was the case of Temme and Verburg (2011). They defined low intensity as being from 0 to $100 \mathrm{~kg}-\mathrm{N}$ input/ha, medium intensity up to $250 \mathrm{~kg}-\mathrm{N}$ input/ha, and high intensity higher than $250 \mathrm{~kg} N$-input/ha. Similarly,

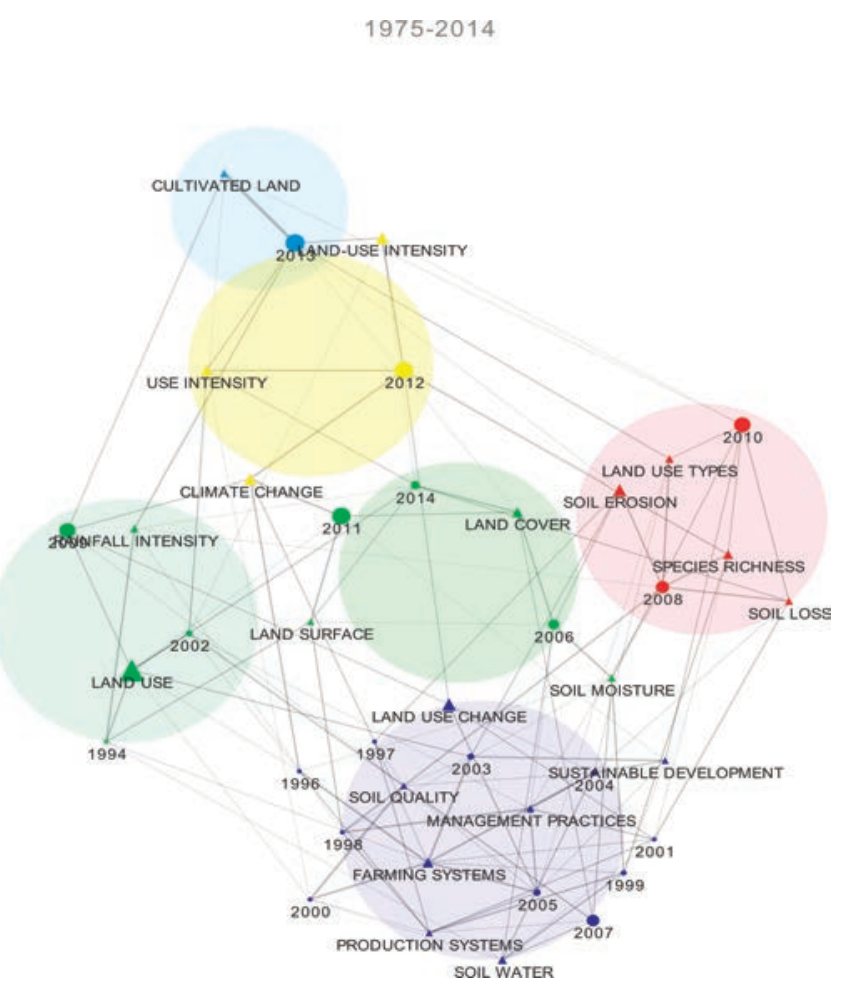

Figure 3. Heterogeneous network of the most common keywords over time (1975-2014) using CorText software. 
nitrogen input rates were classified into three classes: low $(<50 \mathrm{~kg} / \mathrm{ha})$, medium (50-150 kg/ha) and high ( $>150 \mathrm{~kg} / \mathrm{ha})$, based on the relevance for biodiversity (Overmars et al., 2014). Others have defined thresholds based on spent inputs per ha, defining intensive systems as above 250 $€ /$ ha (Reidsma et al., 2006) or $350 € /$ ha of inputs (Audsley et al., 2006). From these works, able to assess whether an indicator increased or decreased over time or if it has different values at different locations, but considering our sample of case studies, we would not able to ascertain whether a farming system was sustainable or not.

\section{The relationship between agricultural intensity and ecosystem services}

In our sample, an average of three indicators is used to evaluate the intensity of a given agricultural area. Often, the total nitrogen input is used as an indicator to ensure a strong link to biodiversity (Temme and Verburg, 2011). This was also confirmed in our sample where a larger number of indicators is used directly on one or a few specific ecosystem services. The studies are also not focused on assessing multiple ecosystem services and most are targeted on a low range of such services (Figure $4 \mathrm{~A})$. We found that the ecosystem services considered in $44 \%$ of our sam- ple are only analysed in cropland systems, which in many cases means an intensive monoculture (Figure 4B). Furthermore in others cases (16\% of the studies), they are analysed globally on land without specifically defining the targeted system of assessment (Verburg et al., 2002; Niedertscheider and Erb, 2014). Many studies do not consider the large diversity of other crops or other kinds of farming systems that are also critically important sources of food (Stoate et al., 2009). For instance, Temme and Verburg (2011) proposed combining European databases to build land-use intensity maps using separate methodologies for arable land and grassland. A few papers analyse $\mathrm{AI}$ in more complex agricultural systems or heterogeneous/mix farming systems in local areas (Figure 4B).

\section{The assessment of agricultural intensity is made at different levels}

The results show a weak trend in the spatial context of the AI changes, as these dynamics are driven by a wide range of indicators operating at different scales (Letourneau et al., 2012). Figure 5A shows the relation between the scale at which an analysis is conducted and the number of indicators used. There were no significant differences between indicator frequencies and study scale. We were also not able to find a clear trend for the indicators used in a specific spatial scale.
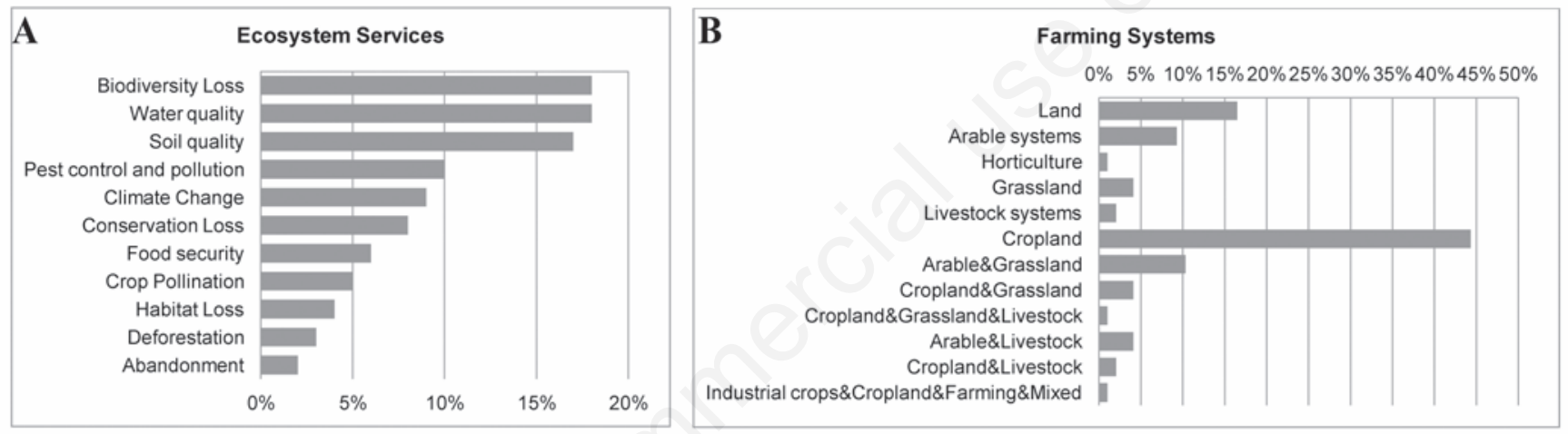

Figure 4. A) Stated relationships between agricultural intensity and ecosystem services in the selected sample. B) Different types of agricultural land use analysed in agricultural intensity studies.

Table 2. Summary of methodological processes and approaches in the different publications.

\begin{tabular}{|c|c|c|}
\hline Scale & Methodology & Reference \\
\hline Farm & $\begin{array}{l}\text { Quantify agricultural inputs related } \\
\text { to land productivity } \\
\text { LUI + multidiversity/biodiversity }\end{array}$ & $\begin{array}{l}\text { Herzog et al., 2006; Reidsma et al., 2006; Geiger et al., 2010; } \\
\text { Armengot et al., 2011; Fumagalli et al., 2011; Nemecek et al., 2011; } \\
\text { Dietrich et al., 2012; Teillard et al., 2012; Gaudino et al., 2014; Jepson et al., } 2014 \\
\text { Flynn et al., 2009; Kleijn et al., 2009; Snapp et al., 2010; Allan et al., 2014; Egorov et al., } 2014\end{array}$ \\
\hline Global to local & Land use changes & $\begin{array}{l}\text { Foley, 2005; Reidsma et al., 2006; Serra et al., 2008; Chen et al., 2009; Rudel et al., 2009; } \\
\text { Yu et al., 2010; Temme and Verbug, 2011; Salvati and Tombolini, 2013; Kandziora et al., } 2014\end{array}$ \\
\hline Regional & Land use change model: CLUE model & Verburg et al., 2002; Lima et al., 2011 \\
\hline Continental & Scenarios of future agricultural land use & Rounsevell et al., 2003; Rounsevell et al., 2005; Audsley et al., 2006 \\
\hline Global to local & $\begin{array}{l}\text { Model simulations + Crop yields; } \\
\text { Modelling farming system dynamics }\end{array}$ & Lobell et al., 2009; Ribeiro et al., 2014 \\
\hline Global to local & Intensity analysis & Aldwaik and Pontius, 2012; Huang et al., 2012 \\
\hline Global to local & Changes in land use and changes in yields & Ewers et al., 2009; Barretto et al., 2013 \\
\hline National & Land use change + HANPP & Erb, 2012; Niedertscheider and Erb, 2014 \\
\hline National & HANPP & Kraussmann et al., 2012 \\
\hline Local & $\begin{array}{l}\text { Urban expansion/population } \\
\text { growth/smallholders }\end{array}$ & Laney, 2002; Petit and Lambin, 2002; Jiang et al., 2013; Nin-Pratt and McBride, 2014 \\
\hline
\end{tabular}

LUI, land use intensity; CLUE model: the conversion of land use and its effects; HANPP, the Human appropriation of net primary production indicator measures both the amount of area used by humans and the intensity of land use. 
Significant differences were found in the frequency of ecosystem services, which yielded clearer trends among study scales. They are more prevalent in studies whose analysis is conducted at a continent level or at different levels and conversely, less prevalent in studies at national and regional levels (Figure 5B).

\section{Common indicators of agricultural intensity}

The indicators identified in each paper and their relations with AI or
LUI provide insights into farming management at different levels (Table 3). Most indicators do not act independently and vary depending on the geographical site, spatial scale, and land use, and their influence changes in different conditions (van Vliet et al., 2015). Based on our sample results, the most commonly used indicators are related to nitrogen fertilisers and the measurement of crop yields ( $\mathrm{kg} / \mathrm{ha}$ or $€ / \mathrm{ha}$ ) (both are used in 18\% of papers). All these indicators (Figure 6) are considered as the most important and at the same time they are the
A

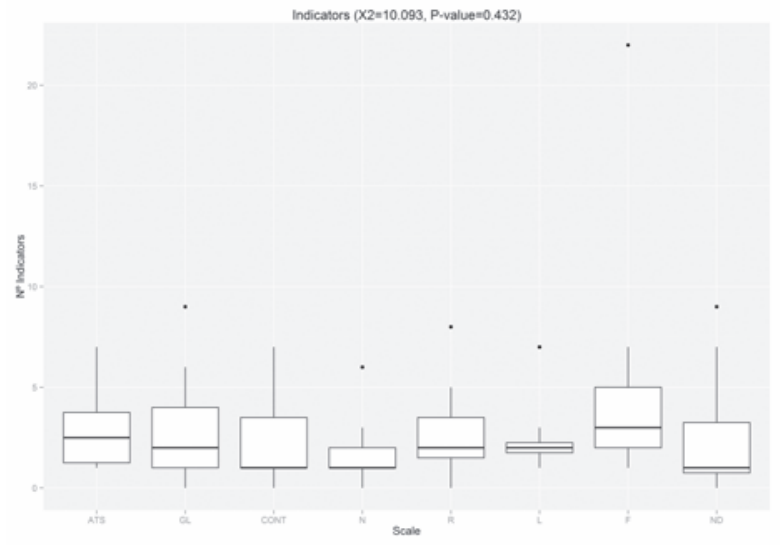

B

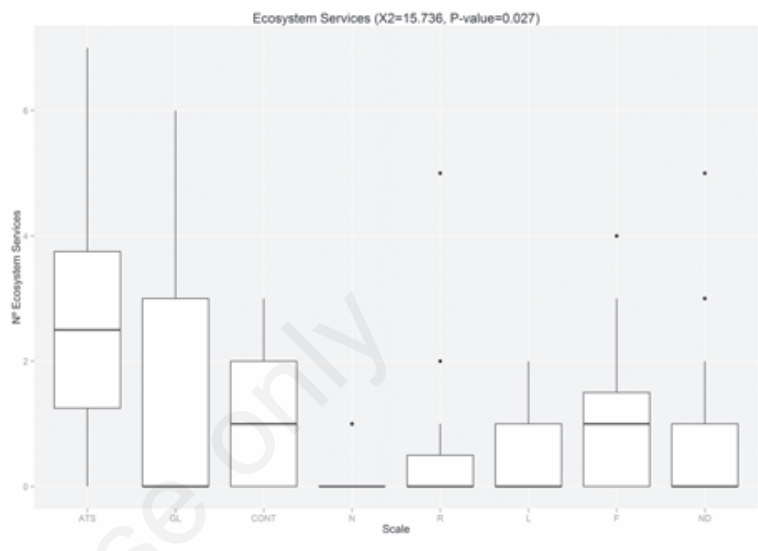

Figure 5. A) Box-plot of number of indicators of agricultural intensity (AI) analysed by scale study (n=105), with Kruskal-Wallis $\chi^{2}$ and $P$ value in brackets. B) Box-plot of number of ecosystem services (related to AI) analysed by scale study ( $n=105)$, with Kruskal-Wallis $\chi^{2}$ and P-value in brackets. ATS, at different scales; GL, global; CONT: continental; N, national; R, regional; L, local; F, farm; ND, not defined.

Table 3. Indicators of agricultural intensity.

\begin{tabular}{|c|c|c|c|}
\hline \multirow[t]{2}{*}{ Reference } & \multicolumn{3}{|c|}{ Summary of the identified indicators at agricultural intensity } \\
\hline & Identified indicators & Region & Discipline \\
\hline $\begin{array}{l}\text { Herzog et al., 2006; Snapp et al., 2010; } \\
\text { Zhang et al., 2012; Gaudino et al., 2014; } \\
\text { Jepson et al., } 2014\end{array}$ & $\begin{array}{l}\text { Mineral fertilisers (NPK) } \\
\text { Organic fertilisers } \\
\text { Pesticides }\end{array}$ & EU, Greece, China, West Africa & $\begin{array}{l}\text { Ecology } \\
\text { Agronomy } \\
\text { Environment }\end{array}$ \\
\hline $\begin{array}{l}\text { Armengot et al., 2011; Fumagalli et al., 2011; } \\
\text { Lu et al., 2012; Erb et al., 2013; Allan et al., 2014; } \\
\text { Egorov et al., } 2014\end{array}$ & $\begin{array}{c}\text { Technologies/labour intensity } \\
\text { Mechanical weed control regime } \\
\text { Mowing frequency (no. of cuts per year) }\end{array}$ & Italy, Spain, Germany China & $\begin{array}{l}\text { Agriculture } \\
\text { Plant sciences } \\
\text { Geography } \\
\text { Ecology }\end{array}$ \\
\hline $\begin{array}{l}\text { Shriar, 2000; Audsley et al., 2006; } \\
\text { Teillard et al., 2012; Barretto et al., } 2013\end{array}$ & $\begin{array}{l}\text { Crop yield (kg/ha)/profitability / } \\
\text { †yield per unit land and time }\end{array}$ & France, UK, Brazil & Environmental science \\
\hline $\begin{array}{l}\text { Serra et al., 2008; Chen et al., 2009; } \\
\text { Teillard et al., 2012; Ribeiro et al., } 2014\end{array}$ & $\begin{array}{l}\uparrow \text { Irrigation } \\
\text { Lowering water table by drainage }\end{array}$ & Spain, China, Portugal & $\begin{array}{l}\text { Geography } \\
\text { Agriculture }\end{array}$ \\
\hline $\begin{array}{l}\text { Laney, 2002; Chen et al., 2009; Nemecek et al., 2011; } \\
\text { Erb et al., 2013; Jiang et al., } 2013\end{array}$ & $\begin{array}{l}\text { Cropping frequency } \\
\text { for a constant unit } \\
\text { of land and time period }\end{array}$ & Switzerland, China & $\begin{array}{c}\text { Geography } \\
\text { Agricultural systems } \\
\text { Environmental sustainability }\end{array}$ \\
\hline $\begin{array}{l}\text { Laney, 2004; Serra et al., 2008; } \\
\text { Schneider et al., 2011; Erb, 2012; } \\
\text { Krausmann et al., 2012; Niedertscheider and Erb, } 2014\end{array}$ & $\begin{array}{c}\text { HANPP } \\
\text { Population (growth) pressure } \\
\text { Spain }\end{array}$ & $\begin{array}{l}\text { EU, Austria, Philippines, } \\
\text { Africa, Italy, China, }\end{array}$ & $\begin{array}{c}\text { Agriculture, } \\
\text { Ecosystems and environment } \\
\text { Agriculture }\end{array}$ \\
\hline $\begin{array}{l}\text { Schneider et al., 2011; Aldwaik and Pontius, 2012; } \\
\text { Huang et al., 2012, Kandziora et al., } 2014\end{array}$ & $\begin{array}{l}\text { Land use change } \\
\text { Transitions: loss or gains } \\
\text { Reallocation land } \\
\text { Land scarcity }\end{array}$ & USA, China, EU & $\begin{array}{c}\text { Geography } \\
\text { Ecosystem management }\end{array}$ \\
\hline $\begin{array}{l}\text { Kristensen et al., 2004; Armengot et al., 2011; } \\
\text { Tuck et al., } 2014\end{array}$ & $\begin{array}{l}\text { Farmers specialising on one or few } \\
\text { (arable) crops instead of mixed farming }\end{array}$ & Spain, Denmark & $\begin{array}{l}\text { Environmental management } \\
\text { Agronomy }\end{array}$ \\
\hline $\begin{array}{l}\text { Caraveli, 2000, Petit and Lambin, 2002; } \\
\text { Geiger et al., 2010; Erb et al., } 2013\end{array}$ & $\begin{array}{l}\text { Shortening of the fallow cycle } \\
\text { Intensive ploughing }\end{array}$ & $\begin{array}{l}\text { Mediterranean countries, } \\
\text { Brussels }\end{array}$ & $\begin{array}{l}\text { Economics } \\
\text { Geography }\end{array}$ \\
\hline $\begin{array}{l}\text { Caviglia-Harris, 2005; Temme and Verburg 2011; } \\
\text { Egorov et al., } 2014\end{array}$ & Cattle grazing or grazing intensity* & Brazilian, EU & $\begin{array}{l}\text { Economy } \\
\text { Environment } \\
\text { Ecology }\end{array}$ \\
\hline
\end{tabular}

HANPP, the Human appropriation of net primary production. * Livestock units per days of grazing ha ${ }^{-1}$ year $^{-1}$. 
easiest to measure both at the farm, continental and global scales. Socio-economic indicators (5\% of papers) were found to a lesser extent, together with those related to regional characteristics such as landscape complexity (2\%), or others associated with farm practices such as water management (8\%).

Yields have increased considerably due to the use of technologies such as mechanisation in large-scale plots or labour intensity (Lambin and Meyfroidt, 2011). According to Bos et al. (2013), these factors have caused a major shift in agricultural systems. In addition, in the $1990 \mathrm{~s}$ a structural change led to the generalised substitution of conventional methods with minimum tillage, for instance by replacing the technologies with more chemical inputs. In arable crop farms in Spain (Moreno Pérez and Ortiz, 2008) this led to a reduction in farm work at the expense of an increase in the use of herbicides (Herzog et al., 2006; Pretty, 2008; Tittonell and Giller, 2013).

Monoculture systems with high levels of pesticides per ha and a specialisation of crops, resulted in a high homogeneity of the landscape (Matson, 1997; Kristensen et al., 2004; Tscharntke et al., 2005; Reidsma et al., 2006; Serra et al., 2008), and showed evidence of high intensity (Caraveli, 2000). However, the assumption that large farms or the increase in farm size indicates a higher intensity of agricultural management has not yet been confirmed (Herzog et al., 2006; Schneider et al., 2011). Thus pesticide inputs are frequently used as significant indicators due to the negative effects and uncontrollable application (Tilman et al., 2002; Foley, 2005; Geiger et al., 2010; Rounsevell et al., 2012; Teillard et al., 2012; Gaudino et al., 2014).

Regarding other agricultural land uses, grassland is one of the dominant forms of land use covering 80 million hectares or $22 \%$ of the EU-25 land area, and thus requires special attention in terms of management (Stoate et al., 2009). The influence of indicators in grassland and livestock farms (Caviglia-Harris, 2005; Bos et al., 2013) is different and in some cases, as in Italy, it has resulted in less intense levels than arable systems (Gaudino et al., 2014). The most common indicators are cattle grazing or grazing intensity (livestock units per day of grazing per ha and year) and the ratio of livestock heads, which also linked to concentrated food for cattle (Temme and Verburg, 2011; Teillard et al., 2012; Allan et al., 2014). At the global level, changes in the agricultural economy and trade, driven by population and economic growth, have led to the expansion and intensification of cultivated and grazing areas, in order to meet the demand for various land-based commodities (Letourneau et al., 2012).

As highlighted by Verburg et al. (2002), in smaller regions, intensively cultivated arable lands are often situated at a limited distance from villages, whereas more extensively managed grasslands are found further away. In these cases, the intensity in heterogeneous systems around cities is measured through other types of indicators, such as land scarcity (Schneider et al., 2011), population growth (DeFries et al., 2004; Hazell and Wood, 2008; Letourneau et al., 2012; Jiang et al., 2013) and labour intensity influenced by the number of smallholders. Intensification is thus increasingly related to agricultural land changes due to: population dynamics in periurban areas (Ewert et al., 2005; Rounsevell et al., 2012), yield increases due to several inputs and market opportunities (Letourneau et al., 2012), and land abandonment (Rey Benayas et al., 2007).

Figure 7 shows a two-dimensional hierarchical cluster analysis analysing the set of indicators identified in each paper, organised according to similarity in indicator composition (horizontal dendrogram). In turn, the indicators are distributed according to their prevalence in the paper samples (vertical dendrogram). Colours indicate a minimum (white) to maximum (black) abundance of indicators indicating the presence in papers. Clearly, the indicator that differed the most was nitrogen fertiliser, well as being the most frequent, followed by crop yield $(\mathrm{kg} / \mathrm{ha})$, technologies and pesticides. They turned out to be more different than the use of organic fertilisers such as manure.

\section{Discussion and conclusions}

We have presented a review of the indicators of AI, based on a sample of papers published in international databases (1975-2014) that dealt with AI from farmland to global levels. Wide differences were found on how to address this phenomenon. Despite several methods for measuring AI and sustainability, our review revealed some important research gaps:

- The farming systems or land use systems analysed in agricultural intensity oriented studies.

We observed that the analysis of agricultural intensification/intensity is conducted on large-scale land use or crop land, in particular monocultural crop systems, whereas there is a lack of studies focused on more complex and heterogeneous systems, e.g., polycultural systems or periurban farming systems. This gap is also reflected by the level of analysis at which these studies are generally performed: global and farm scales are the most common, missing out local and regional studies. These kinds of regional and territorial studies are less easy to perform because of the need for data and methods, as underlined by Benoit et al. (2012) or Boiffin et al. (2014). The methods needed are linked to the upscaling of field/plot research on ecosystem services provided by different agricultural practices (Kragt and Robertson, 2014; Nieto-Romero et al., 2014) and are affected by the difficult assessment of the spatial distribution of cropping and farming systems at a regional level (Leenhardt $e t$ al., 2010).

Geographical distribution of the case studies.

We highlighted that the study of agricultural intensity or intensification in Mediterranean agricultural systems is not being sufficiently addressed. Most research is based on central/northern Europe, whereas the Mediterranean environment would be an interesting case study due to its diversity and also its vulnerability due to the biophysical, climatic and structural conditions (Caraveli, 2000). In recent decades, a major driver of land use changes in these areas has been urban sprawl, i.e., low-density expansion of large urban areas mainly into the surrounding agricultural or natural areas (EEA, 2006). These areas characterised by extensive systems are, however, threatened by the changes in the intensity of farming (Caraveli, 2000; Stoate et al., 2001).

- Indicators and thresholds used to assess agricultural intensity. Indicators are driven differently according to the context and the

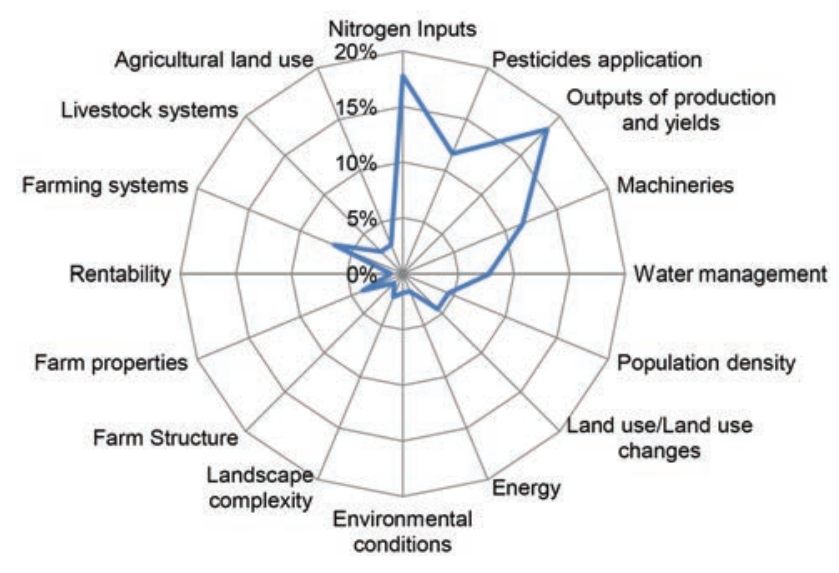

Figure 6. Overview of identified indicators of agricultural intensity in the selected papers $(n=105)$. 


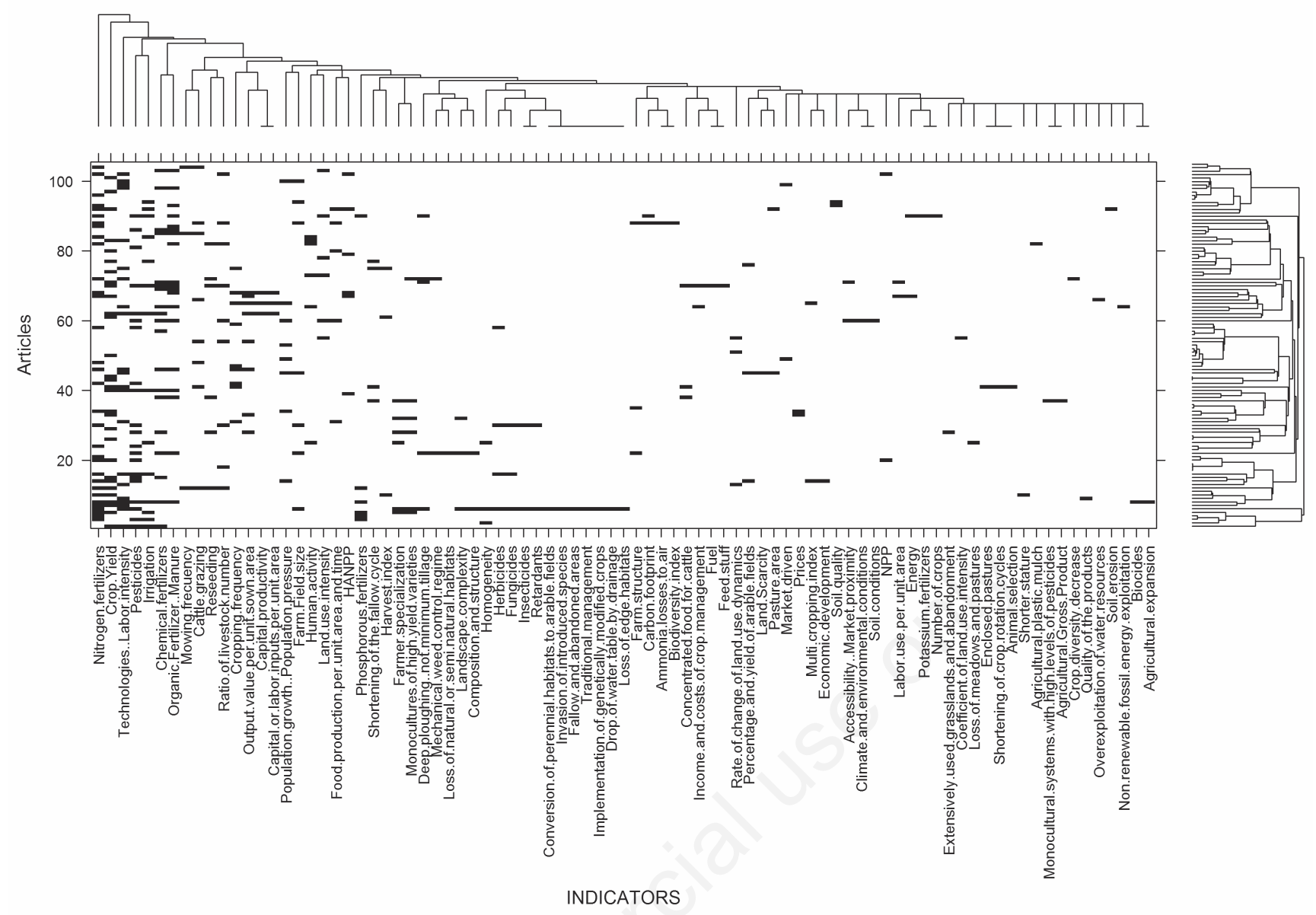

Figure 7. Hierarchical cluster analysis according to similarity in the indicators retrieved in the sample of paper analysed (horizontal dendrogram). Indicators are also organised according to their presence and abundance in the paper sample (vertical dendrogram).

location in which they are measured. It would therefore be useful to include a larger number of case studies across different regions in order to assess a broader range (Rousevell et al., 2012). The studies we sampled show the importance of a major focus on the spatial context in land use intensity changes, as such changes are driven by a wide range of indicators operating at different scales (Letourneau $e t$ al., 2012). Although some studies discuss these approaches, and despite the importance of local studies on farming systems and environmental changes, the rate and magnitude of agricultural intensification have been quantified globally so that, the final outcome in these challenges is not enough.

Because a few thresholds have been defined in the literature, we are able to measure the variability of intensity indicators in a given area or for a given time span per area unit, but this is not enough to measure how intensive or sustainable a system is. To overcome this problem, some authors (Castoldi and Bechini, 2010) proposed defining thresholds with local stakeholders in order to take into account the local preferences for a given ecosystem service or a given indicator.

It is clear that because of the increasing world population, we must continue to increase agricultural production (Bommarco et al., 2013) and therefore we need to understand how and under which conditions agro-ecosystems are altered by agriculture (Matson, 1997; Snapp et al., 2010). Regional and territorial case studies on complex agricultural systems could offer a solution to increasing our knowledge on how to measure and assess agricultural intensity. More multi-scale trials link- ing the plot/field with the territorial levels should be provided in order to evaluate the introduction of innovative and sustainable farming systems. A meta-analysis on case study results would support a further generalisation of local research findings. Finally, the social acceptability of AI or LUI should be tested with local stakeholders.

\section{References}

Aldwaik SZ, Pontius RG, 2012. Intensity analysis to unify measurements of size and stationarity of land changes by interval, category, and transition. Landscape Urban Plan. 106:103-14.

Allan E, Bossdorf 0, Dormann CF, Prati D, Gossner MM, Tscharntke T, Bluthgen N, Bellach M, Birkhofer K, Boch S, Böhm S, Börschig C, Chatzinotas A, Christ S, Daniel R, Diekötter T, Fischer C, Friedl T, Glaser K, Hallmann C, Hodac L, Hölzel N, Jung K, Klein AM, Klaus VH, Kleinebecker T, Krauss J, Lange M, Morris EK, Müller J, Nacke H, Paaali E, Rillig MC, Rothenwöhrer C, Schall P, Scherber C, Schulze W, Socher SA, Steckel J, Steffan-Dewenter I, Türke M, Weiner CN, Werner M, Westphal C, Wolters V, Wubet T, Gockel S, Gorke M, Hemp A, Renner SC, Schöning I, Pfeiffer S, König-Ries B, Buscot B, Linsenmair KE, Schulze E-D, Weisser WW, Fischera M, 2014. Interannual variation in land-use intensity enhances grassland multidiversity. Proc. Natl. Acad. Sci. 111:308-13. 
Armengot L, José-María L, Blanco-Moreno JM, Bassa M, Chamorro L, Sans FX, 2011. A novel index of land use intensity for organic and conventional farming of Mediterranean cereal fields. Agron. Sustain. Develop. 31:699-707.

Audsley E, Pearn KR, Simota C, Cojocaru G, Koutsidou E, Rounsevell MDA, Trnka M, Alexandrov V, 2006. What can scenario modelling tell us about future European scale agricultural land use, and what not? Environ. Sci. Policy 9:148-62.

Barretto AGOP, Berndes G, Sparovek G, Wirsenius S, 2013. Agricultural intensification in Brazil and its effects on land-use patterns: an analysis of the 1975-2006 period. Global Change Biol. 19:1804-15.

Benoît M, Rizzo D, Marraccini E, Moonen AC, Galli M, Lardon S, Rapey H, Thenail C, Bonari E, 2012. Landscape agronomy: a new field for addressing agricultural landscape dynamics. Landscape Ecol. 27: 1385-94.

Benton TG, Vickery JA, Wilson JD, 2003. Farmland biodiversity: is habitat heterogeneity the key? Trends Ecol. Evol. 18:182-8.

Boiffin J, Benoît M, Bail ML, Papy F, Stengel P, 2014. Agronomy, land, and territory: Working on and for territorial development, the stakes for agronomy. Cahiers Agric. 23:72-83.

Bommarco R, Kleijn D, Potts SG. 2013. Ecological intensification: harnessing ecosystem services for food security. Trends Ecol Evol. 28:230-8.

Bos JFFP, Smit A, Bert L, Schröder JJ, 2013. Is agricultural intensification in The Netherlands running up to its limits? NJAS - Wageningen J. Life Sci. 66:65-73.

Boserup E, 1965. The conditions of agricultural growth: the economics of agrarian change under population pressure. Aldine Publishing Company, Chicago, IL, USA.

Buckwell A, 2014. The sustainable intensification of European agriculture. Public utility foundation for rural investment support for Europe (RISE). Available from: http:/www.cap2020. ieep.eu/2014/7/28/sustainable-intensification-of-european-agriculture

Byerlee D, Stevenson J, Villoria N, 2014. Does intensification slow crop land expansion or encourage deforestation? Global Food Security. 3:92-8.

Caraveli H, 2000. A comparative analysis on intensification and extensification in mediterranean agriculture: dilemmas for LFAs policy. J. Rural Stud. 16:231-42.

Cassman KG, 1999. Ecological intensification of cereal production systems: yield potential, soil quality, and precision agriculture. Proc. Natl. Acad. Sci. 96:5952-9.

Castoldi N, Bechini L. 2010. Integrated sustainability assessment of cropping systems with agro-ecological and economic indicators in northern Italy. Eur. J. Agron. 32:59-72.

Caviglia-Harris, 2005. Cattle accumulation and land use intensification by households in the Brazilian Amazon. Agric. Resour. Econ. Rev. 34:145-62.

Chen Y, Li X, Tian Y, Tan M, 2009. Structural change of agricultural land use intensity and its regional disparity in China. J. Geogr. Sci. 19:545-56.

DeFries RS, Foley JA, Asner GP, 2004. Land-use choices: balancing human needs and ecosystem function. Front. Ecol. Environ. 2:249-57.

Dietrich JP, Schmitz C, Müller C, Fader M, Lotze-Campen H, Popp A, 2012. Measuring agricultural land-use intensity - A global analysis using a model-assisted approach. Ecol. Model. 232:109-18.

Egorov E, Prati D, Durka W, Michalski S, Fischer M, Schmitt B, Blaser S, Brändle M, 2014. Does land-use intensification decrease plant phylogenetic diversity in local grasslands? PLoS ONE. 9:e103252.

Erb K-H, 2012. How a socio-ecological metabolism approach can help to advance our understanding of changes in land-use intensity. Ecol. Econ. 76:8-14.

Erb K-H, Haberl H, Jepsen MR, Kuemmerle T, Lindner M, Müller D,
Verburg PH, Reenberg A, 2013. A conceptual framework for analysing and measuring land-use intensity. Curr. Opin. Environ. Sustain. 5:464-70.

Erb K-H, Krausmann F, Gaube V, Gingrich S, Bondeau A, FischerKowalski M, Haberl H, 2009. Analyzing the global human appropriation of net primary production - processes, trajectories, implications. An introduction. Ecol. Econ. 69:250-9.

European Environment Agency (EEA), 2006. Urban sprawl in Europe The ignored challenged. EEA Report No. 10/2006. Available from: http://www.eea.europa.eu/publications/eea_report_2006_10

Ewers RM, Scharlemann JPW, Balmford A, Green RE, 2009. Do increases in agricultural yield spare land for nature? Global Change Biol. 15:1716-26.

Ewert F, Rounsevell MDA, Reginster I, Metzger MJ, Leemans R. 2005. Future scenarios of European agricultural land use I. Estimating changes in crop productivity. Agric. Ecosyst. Environ. 107:101-16.

Flynn DFB, Gogol-Prokurat M, Nogeire T, Molinari N, Richers BT, Lin BB, Simpson N, Mayfield MM, DeClerck F, 2009. Loss of functional diversity under land use intensification across multiple taxa. Ecol. Lett. 12:22-33.

Foley JA, 2005. Global consequences of land use. Science. 309:570-4.

Foley JA, Ramankutty N, Brauman KA, Cassidy ES, Gerber JS, Johnston M, Mueller ND, O'Connell C, Ray DK, West PC, Blazer C, Bennet EM, Carpenter SR, Hill J, Monfreda C, Polasky S, Rockstrom J, Sheehan J, Siebert S, Tilman D, Zaks DPM, 2011. Solutions for a cultivated planet. Nature. 478:337-42.

Fumagalli M, Acutis M, Mazzetto F, Vidotto F, Sali G, Bechini L, 2011. An analysis of agricultural sustainability of cropping systems in arable and dairy farms in an intensively cultivated plain. Eur. J. Agron. 34:71-82.

Gaudino S, Goia I, Borreani G, Tabacco E, Sacco D, 2014. Cropping system intensification grading using an agro-environmental indicator set in northern Italy. Ecol. Indic. 40:76-89.

Geiger F, Bengtsson J, Berendse F, Weisser WW, Emmerson M, Morales MB, Ceryngier P, Liira J, Tscharntke T, Winqvist C, Eggers S, Bommarco R, Part T, Bretagnolle V, Plantegenest M, Clement LW, Dennis C, Palmer C, Onate JJ, Guerrero I, Hawro V, Aavik T, Thies C, Flohre A, Hanke S, Fischer C, Goedhart PW, Inchausti P, 2010. Persistent negative effects of pesticides on biodiversity and biological control potential on European farmland. Basic Appl. Ecol. 11:97-105.

Hazell P, Wood S, 2008. Drivers of change in global agriculture. Philos. Trans. Royal Soc. B Biol. Sci. 363:495-515.

Herzog F, Steiner B, Bailey D, Baudry J, Billeter R, Bukácek R, De Blust G, De Cock R, Dirksen J, Dormann CF, De Filippi R, Frossard E, Liira J, Schmidtg T, Sto ckli R, Thenail C, van Wingerden W, Bugter R, 2006. Assessing the intensity of temperate European agriculture at the landscape scale. Eur. J. Agron. 24:165-81.

Huang J, Pontius RG, Li Q, Zhang Y, 2012. Use of intensity analysis to link patterns with processes of land change from 1986 to 2007 in a coastal watershed of southeast China. Appl. Geogr. 34:371-84.

IFRIS, 2014. CorText. Université Paris-Est 77420 Champs Sur Marne. Available from: http://manager.cortext.net/

Jepson PC, Guzy M, Blaustein K, Sow M, Sarr M, Mineau P, Kegley S, 2014. Measuring pesticide ecological and health risks in West African agriculture to establish an enabling environment for sustainable intensification. Philos. Trans. Royal Soc. B Biol. Sci. 369:20130491.

Jiang L, Deng X, Seto KC, 2013. The impact of urban expansion on agricultural land use intensity in China. Land Use Policy. 35:33-9.

Kandziora M, Dörnhöfer K, Oppelt N, Müller F, 2014. Detecting land use and land cover changes in northern German agricultural landscapes to assess ecosystem service dynamics. Landscape Online. 35:1-24.

Kleijn D, Kohler F, Baldi A, Batary P, Concepcion E, Clough Y, Diaz M, 
Gabriel D, Holzschuh A, Knop E, Kovacs A, Marshall EJP, Tscharntke T, Verhulst J, 2009. On the relationship between farmland biodiversity and land-use intensity in Europe. Proc. Royal Soc. B Biol. Sci. 276:903-9.

Kragt ME, Robertson MJ, 2014. Quantifying ecosystem services tradeoffs from agricultural practices. Ecol. Econ. 102:147-57.

Krausmann F, Gingrich S, Haberl H, Erb K-H, Musel A, Kastner T, Kohlheb N, Niedertscheider M, Schwarzlmüller E, 2012. Long-term trajectories of the human appropriation of net primary production: lessons from six national case studies. Ecol. Econ. 77:129-38.

Kristensen LS, Thenail C, Kristensen SP, 2004. Landscape changes in agrarian landscapes in the 1990s: the interaction between farmers and the farmed landscape. A case study from Jutland, Denmark. J. Environ. Manage. 71:231-44.

Kuemmerle T, Erb K, Meyfroidt P, Müller D, Verburg PH, Estel S, Haberl H, Hostert P, Jepsen MR, Kastner T, Levers C, Lindner M, Plutzar C, Verkerk PJ, van der Zanden EH, Reenberg A, 2013. Challenges and opportunities in mapping land use intensity globally. Curr. Opin. Environ. Sustain. 5:484-93.

Lambin EF, Meyfroidt P, 2011. Global land use change, economic globalization, and the looming land scarcity. Proc. Natl. Acad. Sci. 108:3465-72.

Lambin EF, Rounsevell MDA, Geist HJ, 2000. Are agricultural land-use models able to predict changes in land-use intensity? Agric. Ecosys. Environ. 82:321-31.

Laney RM, 2002. Disaggregating induced intensification for landchange analysis: a case study from Madagascar. Ann. Assoc. Am. Geogr. 92:702-26.

Laney RM, 2004. A process-led approach to modeling land change in agricultural landscapes: a case study from Madagascar. Agric. Ecosyst. Environ. 101:135-53.

Leenhardt D, Angevin F, Biarnès A, Colbach N, Mignolet C, 2010. Describing and locating cropping systems on a regional scale. A review. Agron. Sustain. Develop. 30:131-8.

Letourneau A, Verburg PH, Stehfest E, 2012. A land-use systems approach to represent land-use dynamics at continental and global scales. Environ. Model. Software. 33:61-79.

Liberati A, Altman DG, Tetzlaff J, Mulrow C, Gøtzsche PC, Ioannidis JPA, Clarke M, Devereaux PJ, Kleijnen J, Moher D, 2009. The PRISMA statement for reporting systematic reviews and meta-analyses of studies that evaluate health care interventions: explanation and elaboration. PLoS Med. 339:b2700.

Lima L, Zelaya K, Laterra P, Massone H, Maceira N, 2011. A dynamic simulation model of land cover in the Dulce Creek Basin, Argentina. Proc. Environ. Sci. 7:194-9.

Lobell DB, Cassman KG, Field CB, 2009. Crop yield gaps: their importance, magnitudes, and causes. Ann. Rev. Environ. Resour. 34:179-204.

Lu X, Huang X, Zhong T, Zhao X, Chen Y, Guo S, 2012. Comparative analysis of influence factors on arable land use intensity at farm household level: a case study comparing Suyu District of Suqian City and Taixing City, Jiangsu Province, China. Chinese Geogr. Sci. 22:556-67.

Matson PA, 1997. Agricultural intensification and ecosystem properties. Science. 277:504-9.

Moreno Pérez OM, Ortiz MD, 2008. Understanding structural adjustment in Spanish arable crop farms: policies, technology and multifunctionality. Spanish J. Agric. Res. 6:153.

Nemecek T, Huguenin-Elie 0, Dubois D, Gaillard G, Schaller B, Schaller A, 2011. Life cycle assessment of Swiss farming systems: II. Extensive and intensive production. Agric. Syst. 104:233-45.

Niedertscheider M, Erb K, 2014. Land system change in Italy from 1884 to 2007: analysing the North-South divergence on the basis of an integrated indicator framework. Land Use Policy. 39:366-75.
Nieto-Romero M, Oteros-Rozas E, González JA, Martín-López B, 2014. Exploring the knowledge landscape of ecosystem services assessments in Mediterranean agroecosystems: insights for future research. Environ. Sci. Policy 37:121-33.

Nin-Pratt A, McBride L, 2014. Agricultural intensification in Ghana: evaluating the optimist's case for a Green Revolution. Food Policy. 48:153-67.

Overmars KP, Schulp CJE, Alkemade R, Verburg PH, Temme AJAM, Omtzigt N, Schaminée JHJ, 2014. Developing a methodology for a species-based and spatially explicit indicator for biodiversity on agricultural land in the EU. Ecol. Indicators. 37:186-98.

Paracchini ML, Pacini C, Jones MLM, Pérez-Soba M, 2011. An aggregation framework to link indicators associated with multifunctional land use to the stakeholder evaluation of policy options. Ecol. Indicators. 11:71-80.

Petit CC, Lambin EF, 2002. Long-term land-cover changes in the Belgian Ardennes (1775-1929): model-based reconstruction vs. historical maps. Global Change Biol. 8:616-30.

Pretty J, 2008. Agricultural sustainability: concepts, principles and evidence. Philos. Trans. Royal Soc B Biol. Sci. 363:447-65.

Reidsma P, Tekelenburg T, van den Berg M, Alkemade R, 2006. Impacts of land-use change on biodiversity: an assessment of agricultural biodiversity in the European Union. Agric. Ecosyst. Environ. 114:86-102.

Renting H, Rossing WAH, Groot JCJ, Van der Ploeg JD, Laurent C, Perraud D, Stobbelaar DJ, Van Ittersum MK, 2009. Exploring multifunctional agriculture. A review of conceptual approaches and prospects for an integrative transitional framework. J. Environ. Manage. 90:S112-23.

Rey Benayas J, Martins A, Nicolau J, Shulz J, 2007. Abandonment of agricultural land: an overview of drivers and consequences. CAB Rev. Perspect. Agric. Vet. Sci. Nutr. Nat. Resour. 2:057.

Ribeiro PF, Santos JL, Bugalho MN, Santana J, Reino L, Beja P, Moreira F. 2014. Modelling farming system dynamics in high nature value farmland under policy change. Agric. Ecosyst. Environ. 183:138-44.

Rounsevell MD, Annetts J, Audsley E, Mayr T, Reginster I, 2003. Modelling the spatial distribution of agricultural land use at the regional scale. Agric. Ecosyst. Environ. 95:465-79.

Rounsevell MDA, Berry PM, Harrison PA, 2006. Future environmental change impacts on rural land use and biodiversity: a synthesis of the ACCELERATES project. Environ. Sci. Policy. 9:93-100.

Rounsevell MDA, Ewert F, Reginster I, Leemans R, Carter TR, 2005. Future scenarios of European agricultural land use: II. Projecting changes in cropland and grassland. Agric. Ecosyst. Environ. 107:117-35.

Rounsevell MDA, Pedroli B, Erb K-H, Gramberger M, Busck AG, Haberl H, Kristensen S, Kuemmerle T, Lavorel S, Lindner M, Lotze-Campen H, Metzger MJ, Murray-Rust D, Popp A, Pérez-Soba M, Reenberg A, Vadineanu A, Verburg PH, Wolfslehner B, 2012. Challenges for land system science. Land Use Policy. 29:899-910.

Rudel TK, Schneider L, Uriarte M, Turner BL, DeFries R, Lawrence D, Geoghegan J, Hecht S, Ickowitz A, Lambin EF, Birkenholtz T, Baptista $\mathrm{S}$, Grau R, 2009. Agricultural intensification and changes in cultivated areas, 1970-2005. Proc. Natl. Acad. Sci. 106:20675-80.

Salvati L, Tombolini I, 2013. Cropland vs forests: landscape composition and land-use changes in Peri-urban Rome (1949-2008). WSEAS Trans. Environ. Develop. 9:278-89.

Schneider UA, Havlík P, Schmid E, Valin H, Mosnier A, Obersteiner M, Böttcher H, Skalský R, Balkovi J, Sauer T, Fritz S, 2011. Impacts of population growth, economic development, and technical change on global food production and consumption. Agric. Syst. 104:204-15.

Serra P, Pons X, Saurí D, 2008. Land-cover and land-use change in a Mediterranean landscape: a spatial analysis of driving forces integrating biophysical and human factors. Appl. Geogr. 28:189-209.

Shriar AJ, 2000. Agricultural intensity and its measurement in frontier 
regions. Agroforest. Syst. 49:301-18.

Shriar AJ, 2005. Determinants of agricultural intensity index "scores" in a frontier region: an analysis of data from northern Guatemala. Agric. Human Val. 22:395-410.

Snapp SS, Gentry LE, Harwood R, 2010. Management intensity - not biodiversity - the driver of ecosystem services in a long-term row crop experiment. Agric. Ecosyst. Environ. 138:242-8.

Stoate C, Báldi A, Beja P, Boatman ND, Herzon I, van Doorn A, de Snoo GR, Rakosy L, Ramwell C, 2009. Ecological impacts of early 21st century agricultural change in Europe - a review. J. Environ. Manage. 91:22-46.

Stoate C, Boatman N, Borralho R, Carvalho CR, Snoo GR, Eden P, 2001. Ecological impacts of arable intensification in Europe. J. Environ. Manage. 63:337-65.

Tancoigne E, Barbier M, Cointet J-P, Richard G, 2014. The place of agricultural sciences in the literature on ecosystem services. Ecosyst. Serv. 10:35-48.

Teillard F, Allaire G, Cahuzac E, Léger F, Maigné E, Tichit M, 2012. A novel method for mapping agricultural intensity reveals its spatial aggregation: implications for conservation policies. Agric. Ecosyst. Environ. 149:135-43.

Temme AJAM, Verburg PH, 2011. Mapping and modelling of changes in agricultural intensity in Europe. Agric. Ecosyst. Environ. 140:46-56.

Tilman D, Cassman KG, Matson PA, Naylor R, Polasky S, 2002. Agricultural sustainability and intensive production practices. Nature. 418:671-7.

Tittonell P, Giller KE, 2013. When yield gaps are poverty traps: The par- adigm of ecological intensification in African smallholder agriculture. Field Crops Res. 143:76-90.

Tscharntke T, Klein AM, Kruess A, Steffan-Dewenter I, Thies C, 2005. Landscape perspectives on agricultural intensification and biodiversity - ecosystem service management. Ecol. Lett. 8:857-74.

Tuck SL, Winqvist C, Mota F, Ahnström J, Turnbull LA, Bengtsson J, 2014. Land-use intensity and the effects of organic farming on biodiversity: a hierarchical meta-analysis. J. Appl. Ecol. 51:746-55.

Turner BL, Doolittle WE, 1978. The concept and measure of agricultural intensity. Profess. Geogr. 30:297-301.

Van Vliet J, de Groot HLF, Rietveld P, Verburg PH, 2015. Manifestations and underlying drivers of agricultural land use change in Europe. Landscape Urban Plan. 133:24-36.

Verburg PH, Soepboer W, Veldkamp A, Limpiada R, Espaldon V, Mastura SSA, 2002. Modeling the spatial dynamics of regional land use: the CLUE-S model. Environ. Manag. 30:391-405.

Williams A, Hedlund K, 2014. Indicators and trade-offs of ecosystem services in agricultural soils along a landscape heterogeneity gradient. Appl. Soil Ecol. 77:1-8.

Yu G, Zeng Q, Yang S, Hu L, Lin X, Che Y, Zheng Y, 2010. On the intensity and type transition of land use at the basin scale using RS/GIS: a case study of the Hanjiang River Basin. Environ. Monit. Assess. 160:169-79.

Zhang W, Li H, Sun D, Zhou L, 2012. A statistical assessment of the impact of agricultural land use intensity on regional surface water quality at multiple scales. Int. J. Environ. Res. Public Health. 9:4170-86. 